\title{
IMPLEMENTATION OF LEARNING CONCEPT OF R.A.N.I MODEL ON MASTERY OF MATHEMATICS MATERIAL AT SDN 04 KOTO RANAH LESSON 2015/2016
}

\author{
MASRIDA \\ Volume 1 Nomor 2 \\ JIPS \\ ISSN: 2579-5449 \\ E-ISSN: 2597-6540
}

\begin{abstract}
Primary school age around 6-12 years according to Mulyani Sumantri (Teaching and Learning Strategy 2001: 10) is an important and even fundamental development stage for the success of further development. Involvement in group life (collaboration or cooperation) for elementary school age children is of interest and concern. The development of emotional social relationships and the presence of normative ethical awareness in children of this age is a strong feature of elementary school age. Positive and productive social competencies will develop at this age such as the ability to work together, competence, tolerance, kinship and so on. In connection with the above, in the creation of a child learning environment is a development that provides opportunities for children to work in groups is very important. Giving children the opportunity to ask questions and do the questions in front of the classroom with teacher direction is a practical implication of the social-emotional and moral development of primary school-aged children. From the problems above, in the research can be formulated a formula of the problem as follows: Is the existence of the "Rani" approach in the field of mathematics study can enable fourth grade students SDN 04 Koto Ranah District IV Nagari Bayang Utara Pesisir Selatan District Lesson 2015/2016 year teaching

activities take place? In this classroom action research, the researcher chose the research method with spriral capital proposed by Kemmis and Mc Taggart (1988), as quoted by Kasihani Kasbolah (2001), that in classroom action research, taking planning steps, (action), evaluation (observation / monitoring) and reflection (reflexion). And so on until the research objectives are achieved.

Based on the results of the observation and the results of the problem-solving test, it can be concluded that: Rani's learning model can improve problem solving ability which includes ability to identify problems, determine alternatives, create design, collect data, find solutions and make conclusions on math problems in front of class together on students of Class IV SDN 04 Koto Ranah Sub District IV Nagari Bayang Utara Pesisir Selatan District Lesson Year 2015/2016.

The Rani method improves student activity in class discussions on aspects of conveying opinions, responding to opinions and maintaining opinions. Students generally show a positive response to the implementation of the Rani model. This is indicated by the high percentage of students who provide positive and very positive assessment of learning using Rani model.
\end{abstract}

Keywords: learning concept of model R.A.N.I, mastery of mathematics material 


\title{
IMPLEMENTASI KONSEP PEMBELAJARAN MODEL R.A.N.I TERHADAP PENGUASAAN MATERI MATEMATIKA DI SDN 04 KOTO RANAH TAHUN PELAJARAN 2015/2016
}

\begin{abstract}
ABSTRAK
Masa usia sekolah dasar sekitar $6-12$ tahun menurut Mulyani Sumantri (Strategi Belajar Mengajar 2001 : 10) merupakan tahapan perkembangan penting dan bahkan fundamental bagi kesuksesan perkembangan selanjutnya. Keterlibatan dalam kehidupan kelompok (kolaborasi atau kerja sama) bagi anak usia sekolah dasar merupakan minat dan perhatiannya. Perkembangan hubungan sosial emosional dan adanya kesadaran etis normative pada anak usia ini merupakan ciri yang kuat pada usia sekolah dasar. Kompetensi-kompetensi sosial yang positif dan produktif akan berkembang pada usia ini seperti kemampuan bekerjasama, berkompetensi, toleransi, kekeluargaan dan lain sebagainya.

Sehubungan dengan hal di atas maka dalam penciptaan lingkungan belajar anak adalah pengembangan yang menyediakan kesempatan anak untuk bekerja secara kelompok adalah sangat penting. Pemberian kesempatan anak untuk bertanya dan mengerjakan soal di depan kelas dengan pengarahan guru merupakan implikasi praktis perkembangan sosial-emosional dan moral anak usia sekolah dasar.

Dari permasalahan di atas maka dalam penelitian dapat disusun satu rumusan masalah sebagai berikut : Apakah dengan adanya metode pendekatan "Rani" dalam bidang studi matematika dapat mengaktifkan siswa kelas IV SDN 04 Koto Ranah Kecamatan IV Nagari Bayang Utara Kabupaten Pesisir Selatan Tahun

Dalam penelitian tindakan kelas ini, peneliti memilih cara penelitian dengan modal spriral yang dikemukakan oleh Kemmis dan Mc Taggart (1988), seperti yang dikutip oleh Kasihani Kasbolah (2001), bahwa dalam penelitian tindakan kelas, menempuh langkah-langkah perencanaan (plan), pelaksanaan (action), evaluasi (observation/monitoring) dan perenungan (refleksion). Begitu seterusnya hingga tujuan penelitian tercapai.

Berdasarkan hasil observasi dan hasil tes kemampuan pemecahan masalah dapat disimpulkan bahwa: Model pembelajaran Rani dapat meningkatkan kemampuan pemecahan masalah yang meliputi kemampuan mengindentifikasi persoalan, menentukan alternatif, membuat desain, mengumpulkan data, menemukan solusi dan membuat kesimpulan atas soal matematika di depan kelas secara bersama pada siswa Kelas IV SDN 04 Koto Ranah Kecamatan IV Nagari Bayang Utara Kabupaten Pesisir Selatan Tahun Pelajaran 2015/2016.

Metode Rani meningkatkan aktivitas siswa dalam diskusi kelas pada aspek menyampaikan pendapat, menanggapi pendapat dan mempertahankan pendapat. Siswa secara umum menunjukkan respon positif terhadap pelaksanaan model Rani . Hal ini ditunjukkan dengan tingginya persentase siswa yang memberikan penilaian positif dan sangat positif terhadap pembelajaran menggunanakan model Rani.
\end{abstract} Pelajaran 2015/2016 saat kegiatan mengajar berlangsung?

\section{Kata Kunci: konsep pembelajaran model r.a.n.i, penguasaan materi matematika}




\section{PENDAHULUAN}

Latar Belakang Masalah Penelitian Tindakan Keberhasilan kegiatan belajar siswa di sekolah dipengaruhi oleh banyak faktor. Faktor tersebut dapat bersifat eksternal maupun internal, dan dapat menjadi penghambat atau penunjang proses belajar mengajar. Basuki Wibawa (Media Pengajaran, 2001 : 2) mengemukakan bahwa faktor-faktor yang dianggap turut menghambat proses belajar siswa di kelas mungkin berasal dari verbalisme, kekacauan makna, kegemaran berangan-angan atau persepsi yang tidak tepat. Namun kadang baik guru maupun siswa sering mengabaikannya.

Masa usia sekolah dasar sekitar 6-12 tahun menurut Mulyani Sumantri (Strategi Belajar Mengajar 2001 : 10) merupakan tahapan perkembangan penting dan bahkan fundamental bagi kesuksesan perkembangan selanjutnya. Keterlibatan dalam kehidupan kelompok (kolaborasi atau kerja sama) bagi anak usia sekolah dasar merupakan minat dan perhatiannya. Perkembangan hubungan sosial emosional dan adanya kesadaran etis normative pada anak usia ini merupakan ciri yang kuat pada usia sekolah dasar. Kompetensi-kompetensi sosial yang positif dan produktif akan berkembang pada usia ini seperti kemampuan bekerjasama, berkompetensi, toleransi, kekeluargaan dan lain sebagainya.

Sehubungan dengan hal di atas maka dalam penciptaan lingkungan belajar anak adalah pengembangan yang menyediakan kesempatan anak untuk bekerja secara kelompok adalah sangat penting. Pemberian kesempatan anak untuk bertanya dan mengerjakan soal di depan kelas dengan pengarahan guru merupakan implikasi praktis perkembangan sosial-emosional dan moral anak usia sekolah dasar.

Suatu hal yang biasa, jika dalam kegiatan belajar mengajar banyak sekali persoalan yang dihadapi oleh guru kelas berkenaan dengan pelaksanaan pembelajaran. Salah satunya dalam pelajaran matematika. Kegiatan bertanya jarang terjadi di kelas pada pelajaran ini. Siswa hampir tidak pernah bertanya tentang hal-hal yang prinsipal. Sering kali guru harus menunggu cukup lama sampai siswa mau menjawab pertanyaan yang diajukan. Diskusi antara guru dan siswa atau antara siswa dan siswa sangat jarang terjadi. Ditingkat Sekolah Dasar masalah takut bertanya sering tidak diperhatikan oleh guru. Strategi pembelajaran yang digunakan guru tidak selalu dapat mengurangi rasa takut siswa. Akibatnya siswa merasakan pelajaran matematika sebagai beban, sehingga mengganggu mereka memahaminya jika itu terus terjadi dan tidak diatasi maka murid akan lebih mengalami kesulitan di jenjang pendidikan selanjutnya.

Sebagai tindak lanjut dari keadaan di atas, penulis tertarik untuk memberikan tindakan melalui pendekatan "RANI" dalam pelajaran matematika yang diharapkan mempercepat pemahaman tentang perkalian dan menambah ketertarikan siswa pada pelajaran matematika.

Dari permasalahan di atas maka dalam penelitian dapat disusun satu rumusan masalah sebagai berikut : Apakah dengan adanya metode pendekatan "Rani" dalam bidang studi matematika dapat mengaktifkan siswa kelas IV SDN 04 Koto Ranah Kecamatan IV Nagari Bayang Utara Kabupaten Pesisir Selatan Tahun Pelajaran 2015/2016 saat kegiatan mengajar berlangsung?

Tujuan Penelitan Tindakan, Untuk mengetahui prestasi belajar matematika siswa kelas IV SDN 04 Koto Ranah Kecamatan IV Nagari Bayang Utara Kabupaten Pesisir Selatan Tahun Pelajaran 2015/2016 melalui pendekatan Rani.

\section{METODE PENELITIAN TINDAKAN KELAS}

Setting penelitian, yang menjadi subyek penelitian adalah siswa kelas IV SDN 04 Koto Ranah Kecamatan IV Nagari Bayang Utara Kabupaten Pesisir Selatan Tahun Pelajaran 2015/2016 dalam pelajaran matematika.

Penelitian dilakukan di SDN 04 KOTO RANAH Kecamatan IV Nagari Bayang Utara
Kabupaten Pesisir Selatan dengan keadaan di lokasi sebagai berikut. Letak SD tersebut jauh dari jalan raya dengan alamnya yang masih asri yaitu disebuah desa sehingga keadaan sangat tenang.

SDN 04 Koto Ranah memiliki 1 kepala sekolah yang merangkap menjadi guru kelas, 
empat guru kelas, satu guru agama, dan satu penjaga sekolah. Dan saat dilakukan penelitian belum mempunyai guru olah raga.

Keadaan kelas yang diteliti yaitu pada kelas IV. Rasa saat pelajaran berlangsung, suasana tenang hanya sesekali murid yang menjawab pertanyaan guru. Kebanyakan siswa hanya diam dan menurut apa yang diperintahkan guru tanpa ada yang menyangkal atau bertanya. Dalam pelajaran matematika, guru hanya memberikan ceramah dan contoh soal, setelah itu siswa disuruh mengerjakan soal.

Dalam penelitian tindakan kelas ini, peneliti memilih cara penelitian dengan modal spriral yang dikemukakan oleh Kemmis dan Mc Taggart (1988), seperti yang dikutip oleh Kasihani Kasbolah (2001), bahwa dalam penelitian tindakan kelas, menempuh langkah-langkah perencanaan (plan), pelaksanaan (action), evaluasi (observation/monitoring) dan perenungan (refleksion). Begitu seterusnya hingga tujuan penelitian tercapai.
Rencana penelitian adalah sebagai berikut : Keadaan kelas, pada pelajaran matematika sebelum penelitian dilakukan dapat digambarkan yaitu : Kelas didominasi olah anak-anak yang aktif, keadaan seperti itu dibiarkan oleh guru sehingga siswa yang aktif semakin menjadi siswa yang pendiam.

Hal yang akan dilakukan oleh peneliti : Plan/perencanaan, Action/pelaksanaan, Observasi (evaluasi), Reflection (perenungan)

Instrumen Penelitian Tindakan Peneliti akan menggunakan beberapa media dalam penelitiannya antara lain alat tulis (kertas dan pen) daftar nama siswa dan tabel keaktifan siswa. Untuk mengetahui data tentang siswa yang pasif dan yang aktif maka peneliti membuat tabel tentang keaktifan siswa di dalam kelas. Melalui bantuan guru dan pengamatan.

Karena peneliti menggunakan tabel dan memperhatikan angka dalam mencari data, maka hasil yang diperoleh berupa data kuantitatif.

Berikut ini adalah data sebelum dilakukan penelitian

\begin{tabular}{|l|l|l|l|}
\hline No & Hal yang diamati & $\begin{array}{l}\text { Jumlah } \\
\text { siswa }\end{array}$ & $\begin{array}{l}\text { Presenta } \\
\text { se }\end{array}$ \\
\hline \hline 1 & Siswa mengerjakan soal di depan kelas & 2 & $6 \%$ \\
2 & Siswa mengungkapkan ide & 0 & $0 \%$ \\
3 & Siswa maju ke depan tanpa ditunjuk & 1 & $3 \%$ \\
4 & Siswa bertanya & 5 & $16 \%$ \\
\hline
\end{tabular}

Berdasarkan angket juga diketahui ada 5 siswa (16\%) yang mengatakan bahwa pembelajaran biasa-biasa saja, 15 siswa (50\%) mengatakan bahwa pelajaran matematika menakutkan dan 8 siswa (33\%) mengatakan menjenuhkan sedangkan 5 siswa (16\%) tidak tahu dan 2 siswa (6\%) mengatakan menarik. Setelah dilakukan tindakan diharapkan ada perubahan besar pada diri siswa yaitu sifat percaya diri dan tidak takut pada pelajaran matematika.

Berikut data yang diharapkan setelah dilakukan tindakan pertama

\begin{tabular}{|l|l|l|l|}
\hline No & Hal yang diamati & $\begin{array}{l}\text { Jumlah } \\
\text { siswa }\end{array}$ & Presentase \\
\hline \hline 1 & Siswa mengerjakan soal di depan kelas & 6 & $20 \%$ \\
2 & Siswa mengungkapkan ide & 4 & $13 \%$ \\
3 & Siswa maju ke depan tanpa ditunjuk & 11 & $36 \%$ \\
4 & Siswa bertanya & 9 & $30 \%$ \\
\hline
\end{tabular}

Selain itu hasil data setelah penyebab angket dua dilakukan peneliti mengharapkan perubahan.

Perubahan yang diharapkan 


\begin{tabular}{|l|l|l|l|}
\hline No & Hal yang diamati & $\begin{array}{l}\text { Jumla } \\
\text { h siswa }\end{array}$ & Presentase \\
\hline \hline 1 & Siswa mengerjakan soal di depan kelas & 3 & $10 \%$ \\
2 & Siswa mengungkapkan ide & 10 & $33 \%$ \\
3 & Siswa maju ke depan tanpa ditunjuk & 5 & $16 \%$ \\
4 & Siswa bertanya & 3 & $6 \%$ \\
\hline
\end{tabular}

Jika dalam kenyataan dapat dihasilkan data seperti diatas berarti pembelajaran matematika dengan pendekatan RANI telah berhasil karena memenuhi target.

\section{HASIL PENELITIAN TINDAKAN DAN PEMBAHASAN}

Pelaksanaan Tindakan pada Siklus I, setelah membagi siswa kelas IV dalam kelompok, guru lalu membuka pelajaran dengan menampilkan tema besar permasalahan. Dilanjutkan dengan memberi penjelasan tentang hal-hal yang harus dipersiapkan untuk melakukan penyelidikan. Setelah siswa memperoleh kejelasan tentang apa yang akan dilakukannya, guru mempersiapkan siswa untuk bekerja secara mandiri dengan kelompoknya dalam melakukan kegiatan penyelidikan. Bersamaan dengan itu guru membimbing siswa melalui tahap-tahap penyelidikan secara runtut sampai dengan menemukan solusi permasalahan yang dipilih oleh masing-masing kelompok. Kemudian tiap-tiap kelompok membuat hasil karya kelompok yang dipresentasikan di depan kelas atau melakukan diskusi kelas. Setelah semua kegiatan selesai dilakukan, selanjutnya berdasarkan pengamatan guru terhadap siswa maka diperoleh data sebagai berikut: Kemampuan siswa dalam memecahkan masalah pada siklus I dapat dilihat pada hasil observasi selama proses pembelajaran berlangsung dan dari hasil tes kemampuan pemecahan masalah. Persoalan yang dikaji pada siklus I adalah Bagaimana cara kreativitas siswa dalam mengerjakan soal di depan kelas.

Masih ada kategori yang tidak muncul dengan persentase yang cukup besar yaitu pada kemampuan membuat desain penelitian. Untuk kemampuan Menentukan alternatif dan kemampuan membuat kesimpulan, sudah berada dalam kategori baik. Sedangkan untuk kemampuan yang lain yaitu Mengidentifikasi persoalan, mengumpulkan data dan menemukan solusi masih dalam kategori kurang baik. Kemampuan membuat desain penelitian masih kurang baik karena sebelumnya siswa tidak terbiasa untuk merancang kegiatan penelitian sendiri. Kalaupun melakukan aktivitas penyelidikan, tahap-tahapnya sudah dirancang oleh guru. Sehingga ketika mereka diharuskan untuk membuat rancangan penelitian sendiri, siswa masih merasa kesulitan.

Persoalan-persoalan yang diidentifikasi oleh siswa dalam siklus I ini antara lain : Cara mengemukakan pendapat dalam mengerjakan soal matematika di depan kelas". Alternatifalternatif yang dikemukakan oleh siswa antara lain " mendengarkan pendapat dari sesama siswa di depan kelas". Kesimpulan yang dibuat oleh siswa antara lain " terjadi dialog yang sopan dan saling memberi masukan atas perbincangan tersebut". Data kemampuan pemecahan masalah pada siswa dari hasil tes tertulis disajikan pada Tabel 2,

Bila dibandingkan dengan kemampuan awal pemecahan masalah, pada siklus I terjadi peningkatan persentase pada aspek-aspek kemampuan pemecahan masalah. Dari Tabel 2. di atas dapat dilihat bahwa ada beberapa aspek kemampuan berada dalam kategori sangat baik, di mana sebagian besar siswa $(>75 \%)$ sudah bisa menjawab soal dengan baik yaitu menemukan permasalahan dan menemukan alternatifalternatif penyelesaian, sedangkan aspek-aspek yang lain yaitu membuat rancangan penyelidikan, menemukan data yang relevan, menemukan solusi dan membuat kesimpulan berada pada kategori baik (50 sampai 75\%). Jika dibandingkan, ada sedikit perbedaan antara kemampuan pemecahan masalah dilihat dari hasil observasi dan hasil tes tertulis. Hasil tes tertulis menunjukkan bahwa hampir semua soal bisa dijawab oleh sebagian besar siswa, kecuali soal yang mengindikasikan kemampuan membuat desain. Sedangkan hasil observasi menunjukkan bahwa sebagian besar siswa belum mampu melakukan proses pemecahan masalah dengan baik. Perbedaan ini dikarenakan, kemampuan pemecahan masalah berdasarkan 
hasil observasi diamati pada saat kegiatan berlangsung sedangkan tes dilakukan sesudah pembelajaran,sehingga siswa sudah mempunyai gambaran yang cukup jelas tentang soal-soal yang ditanyakan tersebut. Dan dalam hal ini, hasil observasi dianggap lebih akurat karena diamati pada saat siswa melakukan aktivitas yang menunjukkan kemampuan tersebut. Sedangkan hasil tes tertulis digunakan untuk mendukung hasil observasi untuk mengetahui sejauh mana siswa mengingat apa yang telah dilakukannya dan mempergunakannnya untuk menjawab soal yang menunjukkan aspek kemampuan pemecahan masalah.

Aktivitas siswa dalam diskusi kelas ini didapatkan dari hasil observasi selama diskusi kelas berlangsung. Dari data di atas dapat dilihat bahwa pada siklus I, aktivitas siswa dalam diskusi kelas masih rendah baik dari segi kualitas maupun kuantitas. Terlihat dari masih sedikitnya jumlah siswa yang berpartisipasi dalam kegiatan diskusi kelas. Hal ini dikarenakan siswa maih enggan untuk ikut terlibat baik itu menyatakan pendapat, menanggapi pendapat maupun mempertahankan pendapat karena takut salah. Hal ini masih membuka peluang untuk ditingkatkan pada siklus II.

Secara umum keterlaksanaan proses pembelajaran berbasis persoalan sudah baik. Berdasarkan diskusi antara guru mata pelajaran matematika dan observasi didapatkan kesimpulan bahwa dalam pemecahan masalah oleh siswa dan kerjasama siswa dalam kelompok masih belum optimal. Masih banyak siswa yang cenderung mengandalkan teman satu kelompok. Hal ini terlihat dari tahapan IV yang hanya mencapai $56,25 \%$. Demikian juga pada tahapan pengungkapan kembali cara penyelesaian masalah, belum semua siswa dapat terlibat. Selain karena enggan, juga karena siswa belum mengerti benar apa yang harus dilakukan pada tahap ini.

Refleksi setelah dilakukan refleksi terhadap proses pembelajaran matematika pada siklus I, maka pada siklus II ada hal-hal yang perlu diperhatikan yaitu: 1) Guru perlu memberikan motivasi kepada siswa untuk terlibat dalam proses pemecahan masalah, karena hal ini mempengaruhi proses pemecahan masalah oleh siswa. 2) Guru perlu memberikan contoh yang dekat dengan kehidupan sehari-hari agar siswa lebih mudah masuk dalam permasalahan yang disajikan. 3) Dalam pengungkapan kembali, perlu adanya penjelasan lagi tentang apa yang baru saja dilakukan siswa, agar siswa menjadi lebih jelas. 4) Guru perlu menginformasikan bahwa segala aktivitas serta partisipasi siswa masuk dalam kriteria penilaian.

Pada siklus II, siswa belajar tentang faktor-faktor yang mempengaruhi perilaku siswa. Persoalan yang dikaji adalah perbedaan pendapat atas jawaban soal yang berbeda.

Tindakan pada siklus II dilakukan berdasarkan dari kegiatan tindakan pada siklus I yang telah direfleksi dan dilakukan perbaikan. Rekomendasi dari siklus I adalah: 1) Guru perlu memberikan motivasi kepada siswa untuk terlibat dalam proses pemecahan masalah, karena hal ini mempengaruhi proses pemecahan masalah oleh siswa. 2) Guru perlu memberikan contoh yang dekat dengan kehidupan sehari-hari agar siswa lebih mudah masuk dalam permasalahan yang disajikan. 3) Dalam pengungkapan kembali, perlu adanya penjelasan lagi tentang apa yang baru saja dilakukan siswa, agar siswa menjadi lebih jelas. 4) Guru perlu menginformasikan bahwa segala aktivitas serta partisipasi siswa masuk dalam kriteria penilaian.

Setelah dilakukan pengumpulan data menggunakan instrumen monitoring terhadap pembelajaran pada siklus II diperoleh hasil sebagai berikut:

Kemampuan siswa dalam memecahkan masalah pada siklus II dapat dilihat pada hasil observasi selama proses pembelajaran berlangsung dan dari hasil tes kemampuan pemecahan masalah. Persoalan yang dikaji pada siklus II adalah faktor-faktor yang mempengaruhi Perilaku siswa dapat dilihat bahwa pada siklus II aspek dengan kategori tidak muncul sudah tidak ada. Bahkan pada kategori baik dan sangat baik terjadi peningkatan persentase untuk semua aspek. Yang artinya pada siklus II ini siswa sudah menunjukkan kategori baik pada semua aspek kemampuan. Data kemampuan pemecahan masalah pada siswa dari hasil tes dapat dilihat bahwa semua aspek sudah berada dalam kriteria baik, dalam arti bahwa sebagian besar siswa (>75\%) sudah dapat menjawab pertanyaan yang mengindikasikan kemampuan pada aspek-aspek tersebut. Hampir semua aspek menunjukkan peningkatan persentase, kecuali pada aspek kedua yang mengalami penurunan dari $100 \%$ menjadi $97,73 \%$. Jika dibandingkan dengan hasil observasi, sudah ada kesinkronan antara kemampuan pemecahan masalah yang dilihat dari hasil tes tertulis dan dari hasil observasi. Hal 
ini berarti bahwa siswa selain dapat melakukan aktivitas kemampuan pemecahan masalah dalam kategori baik, juga dapat menjawab pertanyaan yang mengindikasikan aspek-aspek kemampuan pemecahan masalah tersebut.

Aktivitas siswa dalam diskusi kelas ini didapatkan dari hasil observasi selama diskusi kelas berlangsung. Dari data di atas dapat dilihat adanya peningkatan persentase siswa yang terlibat dalam diskusi kelas dan rata-rata telah berkriteria baik, meskipun masih ada yang berkriteria kurang baik yakni sebesar 15,9\% (7 orang) pada aspek mempertahankan pendapat.

Pada siklus II, keterlaksanaan proses pembelajaran Matematika menggunakan model pembelajaran Rani berkisar antara 75 sampai $87,5 \%$. Peningkatan terjadi pada semua tahapan pembelajaran Rani jika dibandingkan dengan siklus I. Hal ini menunjukkan adanya peningkatan yang cukup berarti pada keterlibatan siswa dalam pemecahan masalah dan kerjasama dalam kelompok. Demikian juga dengan keterlibatan siswa dalam pengungkapan kembali pemecahan masalah.

d. Tanggapan siswa terhadap pelaksanaan model Rani

Pada akhir siklus II, diberikan angket kepada siswa untuk mengetahui tanggapan siswa terhadap pelaksanaan pembelajaran matematika dengan menggunakan model Rani . Penilaian siswa berkisar antara sangat positif sampai sangat negatif.

Keterangan Kategori $1=$ Siswa memberikan penilaian yang sangatcofffgatlfing. Scaffolding adalah proses dimana Kategori 2 = Siswa memberikan penilaian yang negatifseorang yang lebih banyak pengetahuannya, Kategori 3 = Siswa memberikan penilaian yang positłfalam hal ini guru, membantu seseorang yang Kategori 4 = Siswa memberikan penilaian yang sangdeleibsideflikit pengetahuannya untuk menuntaskan

Kemampuan pemecahan masalah dapat dievaluasi melalui observasi dan tes tertulis. Dari observasi terhadap kegiatan yang siswa lakukan diperoleh informasi tentang apa yang dapat dilakukan oleh siswa (performance). Selain itu juga dapat menggunakan tes tertulis yang menggambarkan kemampuan tersebut. Baik hasil observasi maupun hasil tes kemampuan pemecahan masalah dapat saling melengkapi untuk menunjukkan kemampuan pemecahan masalah pada siswa.

Kemampuan pemecahan masalah pada siswa yang dilihat dari hasil observasi selama proses pembelajaran menggunakan model Rani menunjukkan bahwa model ini mampu mengembangkan kemampuan pemecahan masalah pada siswa, karena selama proses pembelajaran menggunakan model Rani memungkinkan siswa dituntut untuk dapat menemukan solusi dari permasalahan yang dekat dengan kehidupan sehari-hari. Untuk dapat menemukan solusi permasalahan tersebut, siswa harus melakukan tahapan-tahapan pemecahan masalah. Tahapan-tahapan tersebut adalah: mengidentifikasi permasalahan, menemukan alternatif-alternatif penyelesaian, merancang desain penyelidikan, mencari data yang relevan, menemukan solusi terbaik dan membuat kesimpulan.

Peningkatan kemampuan pemecahan masalah terlihat antara siklus I dan siklus II. Kategori tidak muncul dalam melakukan proses pemecahan masalah untuk beberapa indikator masih ada yaitu mengidentifikasi permasalahan, membuat desain penyelidikan, mencari data yang relevan dan menemukan solusi.

Pada siklus II tidak ada lagi aspek yang memiliki kategori tidak muncul yang berarti pada siklus II semua siswa telah melakukan proses pemecahan masalah dalam kategori kurang baik, baik dan sangat baik. Kemampuan menemukan alternatif-alternatif penyelesaian dan membuat kesimpulan antara siklus I dan siklus II ditunjukkan dengan kategori baik, tetapi pada siklus II terjadi peningkatan persentase yang berarti pada siklus II ada peningkatan jumlah siswa yang dapat melakukan kemampuan tersebut dengan baik.

Hal ini menunjukkan adanya keberhasilan guru dalam melakukan salah satu proses yaitu tifseorang yang lebih banyak pengetahuannya,
tifalam hal ini guru, membantu seseorang yang suatu masalah melampaui tingkat pengetahuannya saat ini (Ibrahim dan Nur, 2000).

Untuk aspek mengidentifikasi permasalahan, membuat desain penyelidikan, menemukan data-data yang relevan dan menemukan solusi yang pada siklus I ditunjukkan oleh kategori kurang baik meningkat menjadi kategori baik pada siklus II. Secara umum terjadi peningkatan persentase siswa yang dapat melakukan kemampuan pemecahan masalah untuk kategori sangat baik. Dengan demikian model pembelajaran Rani dapat mengembangkan kemampuan pemecahan masalah pada siswa.

b. Kemampuan pemecahan masalah yang dilihat dari hasil tes tertulis 
Kemampuan pemecahan masalah yang dilihat dari hasil tes tertulis dapat diketahui dari aspek pemecahan masalah yang menggambarkan kemampuan mengidentifikasi permasalahan, menemukan alternatif-alternatif penyelesaian, membuat desain penyelidikan, mencari data yang relevan, menemukan solusi terbaik dan membuat kesimpulan.

Jika dibandingkan dengan data awal kemampuan pemecahan masalah, pada siklus I terjadi peningkatan persentase pada beberapa aspek kemampuan pemecahan masalah yaitu aspek membuat desain penelitian, menemukan solusi dan membuat kesimpulan. Antara siklus I dan siklus II, kemampuan mengidentifikasi permasalahan dan menemukan alternatifalternatif penyelesaian sangat baik berarti pada siklus I dan siklus II sebagian besar (>75\%) siswa mampu menjawab dengan benar soal yang menggambarkan kemampuan tersebut. Untuk aspek membuat desain penyelidikan, mencari data yang relevan, menemukan solusi terbaik dan membuat kesimpulan pada siklus I ditunjukkan oleh kategori baik dimana 50 sampai $75 \%$ siswa dapat menjawab soal tersebut dengan benar dan meningkat menjadi sangat baik pada siklus II dimana sebagian besar siswa (>75\%) dapat menjawab soal tersebut dengan benar.

Selain itu juga terjadi penurunan dan peningkatan persentase antara siklus I dan siklus II. Penurunan persentase terjadi pada aspek menemukan alternatif-alternatif penyelesaian dari $100 \%$ menjadi $97,73 \%$, meskipun masih tetap berada pada kategori sangat baik. Untuk kemampuan yang lain terjadi peningkatan antara siklus I dan siklus II. Hal ini berkaitan dengan aktivitas siswa selama pembelajaran.

Tingkat aktivitas siswa dalam diskusi kelas meliputi aspek menyampakan pendapat, menanggapi pendapat dan mempertahankan pendapat. Secara umum antara siklus I dan siklus II terjadi peningkatan persentase siswa yang aktif dalam diskusi kelas, pada semua aspek (Tabel 3. dan Tabel 7.). Pada siklus I tingkat aktiviats siswa dalam menyampaikan pendapat sudah baik dalam arti pendapat rasional tetapi kurang benar. Dalam menanggapi pendapat (menyetujui atau menyanggah) masih dengan alasan yang kurang tepat. Demikian pula dalam mempertahankan pendapat juga masih dengan argumen yang kurang tepat.

Dengan menginformasikan bahwa aktivitas siswa dalam diskusi kelas masuk dalam penilaian, membuat persentase siswa yang ikut terlibat dalam diskusi kelas menjadi meningkat pada siklus II. Secara kualitas juga terjadi peningkatan siswa yang melakukan aktivitas diskusi kelas dengan kategori sangat baik. Hal ini sesuai dengan salah satu poin penting, yaitu menfasilitasi pengembangan kemampuan kelompok (Anonim, 2003) dan sesuai dengan yang disampaikan oleh Robbs dan Merideth (Greening, 2003) bahwa salah satu keuntungannya adalah peningkatan hubungan antar siswa.

\section{KESIMPULAN DAN SARAN}

Berdasarkan hasil observasi dan hasil tes kemampuan pemecahan masalah dapat disimpulkan bahwa: 1. Model pembelajaran Rani dapat meningkatkan kemampuan pemecahan masalah yang meliputi kemampuan mengindentifikasi persoalan, menentukan alternatif, membuat desain, mengumpulkan data, menemukan solusi dan membuat kesimpulan atas soal matematika di depan kelas secara bersama pada siswa Kelas IV SDN 04 Koto Ranah Kecamatan IV Nagari Bayang Utara Kabupaten Pesisir Selatan Tahun Pelajaran 2015/2016 . 2.

Metode Rani meningkatkan aktivitas siswa dalam diskusi kelas pada aspek menyampaikan pendapat, menanggapi pendapat dan mempertahankan pendapat. 3. Siswa secara umum menunjukkan respon positif terhadap pelaksanaan model Rani . Hal ini ditunjukkan dengan tingginya persentase siswa yang memberikan penilaian positif dan sangat positif terhadap pembelajaran menggunanakan model Rani

Saran, agar model pembelajaran Rani dapat diterapkan dengan baik dan berhasil maka guru harus dapat menyajikan persoalan yang otentik dan berkait dengan kehidupan nyata, sehingga siswa bisa merasa tertarik untuk terlibat dalam proses pembelajaran dan pemecahan masalah tersebut. Rani dapat diterapkan pada pokok bahasan lain selama pokok bahasan tersebut memiliki persoalan yang otentik untuk dikaji. 


\section{DAFTAR PUSTAKA}

Basuki Wibawa. (2001). Media Pengajaran. Mulyono Abdulrahman. (1999). Pendidikan Bandung : CV. Maulana.

Bobby Deporter dan Mike Hernaeki. (2003). Quantum Learning : Nuansa. Bagi anak Kesulitan Belajar : Departemen Pendidikan dan Kebudayaan.

Conny Seiawan. (2001). Pendekatan Keterampilan Proses. Jakarta : Gramedia.

Suharsimi Arikunto. ( 2000). Pengelolaan Kelas dan Siswa. Jakarta : PT Raja Grafindo Persada.

Nasibuan. ( 2003). Proses Belajar Mengajar. Sujati. (2003). Laporan Pendidikan.

Bandung : PT Remaja Rasdakarya.

Heinz Krek. (1999). Saya Guru yang Baik ?. Syaiful Babri Djamarah. (2000). Guru dan Jakarta : KANISIUS.

Kartika Budi. (1999). Jurna I Penelitian Pendidikan Dasar : Universitas Sanatadarma Yogyakarta.

Kasihani Kaskolah. (2001). Penelitian Tindakan Kelas : Universitas Negeri Malang.

Mulyami Sumantri \& Johar Permona. (2001). Strategi Belajar Mengajar. Bandung : Anak Didik dalam Interaksi Edukatif. Jakarta : PT Aneka Cipta.

Tombokan Runtukahu. ( 2002). Pengajaran Matematika bagi Anak Berkesulitan Belajar : Departemen Pendidikan dan Kebudayaan.

Uragg. (1996). Pengelolaan Kelas (saduran Anwar Jasih). Jakarta : Grasindo. 